\section{Root Epidermal Adhesion in Five Sweetpotato Cultivars during Curing and Storage}

\author{
Sylvia M. Blankenship ${ }^{1}$ \\ Department of Horticultural Science, North Carolina State University, Raleigh, \\ NC 27695
}

Michael D. Boyette ${ }^{2}$

Department of Biological and Agricultural Engineering, North Carolina State University, Raleigh, NC 27695

Additional index words. Ipomoea batatas, epidermis, postharvest physiology, quality, skinning

\begin{abstract}
Beauregard', 'Jewel', 'Hernandez', 'Carolina Rose', and 'White Delight' sweetpotato [Ipomoea batatas (L.) Lam.] roots were placed in chambers for curing at $30{ }^{\circ} \mathrm{C}$ and $50 \%, 70 \%$, or $85 \%$ relative humidity (RH) for 1 week. Uncured roots were held at $15{ }^{\circ} \mathrm{C}$ and $90 \% \mathrm{RH}$. After curing, roots were removed temporarily from the chambers, and chamber conditions were reset for the following storage treatments: $15{ }^{\circ} \mathrm{C} / 85 \% \mathrm{RH}$; $18{ }^{\circ} \mathrm{C} / 70 \% \mathrm{RH}$; and $18{ }^{\circ} \mathrm{C} / 50 \% \mathrm{RH}$. Roots were stored 3 to 4 weeks. Experiments were in factorial arrangements so all combinations of curing and storage conditions were present. Experiments were conducted in two seasons. Roots were subjected to a pressurized water jet and the amount of skinning that occurred was visually rated several times during curing and storage. Weight loss was measured in 'Beauregard'. Susceptibility to skinning changed over time and with the temperature and humidity conditions. Curing at $30{ }^{\circ} \mathrm{C}$ and any humidity between $50 \%$ and $85 \%$ generally improved epidermal adhesion, but there were exceptions. Lower humidities promoted greater weight loss. Epidermal adhesion changed during storage, becoming both stronger and weaker, indicating that sweetpotato epidermis is in an active state even after curing. The standard curing and storage conditions of $30{ }^{\circ} \mathrm{C} / 85 \% \mathrm{RH}$ and $15{ }^{\circ} \mathrm{C} / 85 \% \mathrm{RH}$, respectively, are still a reasonable practice.
\end{abstract}

Curing after harvest and subsequent storage of sweetpotatoes has been done for many years. In a 1925 U.S. Dept. of Agriculture (USDA) bulletin, there is a description of curing roots for 10 to $14 \mathrm{~d}$ at 80 to $85^{\circ} \mathrm{F}(26.5$ to $29.5^{\circ} \mathrm{C}$ ) using a fire to maintain the temperature and drive out moisture (Thompson, 1925). A 1943 publication states that sweetpotatoes should be cured at $\approx 80^{\circ} \mathrm{F}(26.5$ ${ }^{\circ} \mathrm{C}$ ) with $90 \%$ to $95 \%$ relative humidity (RH) (Miller, 1943). Current standard industry curing conditions are $30^{\circ} \mathrm{C}$ and $85 \%$ RH for about a week. Curing is said to "set the skin" (i.e., epidermis), heal the wounds (i.e., promote periderm formation) and make the roots less likely to skin during further handling.

Most sweetpotato storage publications recommend a storage temperature of 13 to $16^{\circ} \mathrm{C}$, with cautions on chilling injury (Boyette et al., 1997; Hardenburg et al., 1986). Newer curing

Received for publication 2 Oct. 2000. Accepted for publication 25 July 2001. Mention of a trademark or proprietary product does not constitute a guarantee or warranty of the product by either the NCARS or USDA and does not imply its approval to the exclusion of other products that may also be suitable. This research was supported in part by funding from the North Carolina Sweetpotato Commission.

${ }^{1}$ Professor. To whom reprint requests should be addressed.

${ }^{2}$ Associate Professor. and storage systems utilize precise temperature and humidity control, such as in horizontal ventilation systems (Boyette and Stewart, 1994).

It is well known that injured roots don't store well and farmers have long been cautioned to dispose of injured roots (Miller, 1943; Thompson, 1925). Sweetpotato epidermis is susceptible to damage during harvesting and packing. Often the epidermis will tear loose from the underlying tissue leaving a wound, in a process termed "skinning." The skinned portion of the root is visually unappealing, creates a path for water loss, increases weight loss, and provides an entrance for disease organisms. It was found that curing at near $100 \%$ relative humidity $(\mathrm{RH})$ was best for avoiding weight loss due to injuries on sweetpotatoes (Kushman, 1975). The tendency toward skinning is not constant during root harvesting and storage (Boyette et al., 1997). Pre-harvest field practices, such as vine dessication and removal, are thought to reduce skinning (La Bonte and Wright, 1993). Weight loss is a major concern in sweetpotato storage. It has been shown that transpiration is the greatest source of weight loss, although there is a contribution of respiration (Picha, 1986). gate the curing and storage temperatures and humidities for some of the newer sweetpotato cultivars with an emphasis on which condi-
The objective of this study was to investi- tions would give a root the toughest, most skinning resistant epidermis. We also wanted to see the effect of seasonal variations and harvest date on skinning and if changes in skinning response occurred during storage.

\section{Materials and Methods}

In the first year of study (1996) the following cultivars were tested: 'Beauregard', 'Jewel', 'White Delight', 'Carolina Rose', and 'Hernandez'. In the second year (1997), only 'Beauregard' and 'Jewel' were tested. There were two harvest dates in each season for 'Hernandez', 'Beauregard', and 'Jewel'. Planting dates varied between years and among cultivars. Roots were grown under standard commercial practices on experiment station farms or on commercial farms in eastern North Carolina. Roots were mechanically harvested and handled to minimize skinning. U.S. Grade No. 1 size roots were selected. Roots were gently washed in water, allowed to air dry, then placed in paper bags (usually eight roots/ bag).

Studies were conducted at the Southeastern Plant Environment Laboratory, Raleigh, N.C. Roots were placed in chambers for curing at $30{ }^{\circ} \mathrm{C}$ with $50 \%, 70 \%$, or $85 \% \mathrm{RH}$ for 1 week. Uncured roots were held continuously at $15{ }^{\circ} \mathrm{C}$ and $90 \% \mathrm{RH}$. After curing, roots were removed temporarily from the chambers, and chamber conditions were reset for the following storage treatments: $15^{\circ} \mathrm{C} / 85 \% \mathrm{RH} ; 18^{\circ} \mathrm{C} /$ $70 \% \mathrm{RH}$; and $18{ }^{\circ} \mathrm{C} / 50 \% \mathrm{RH}$. These treatments were selected to represent the industry standard, and two warmer, drier environments, since there was anecdotal evidence that warmer, drier environments created roots with a stronger epidermis. Experiments were in a factorial arrangement so all combinations of curing and storage conditions were present. In the storage studies there were nine curing/storage treatment combinations. All treatments took place in the dark. Roots were stored for either 3 or 4 weeks. Epidermal adhesion was tested at harvest, after curing, and once a week during storage. Roots were removed from the chambers, tested and then returned to the chambers. The same roots were tested each week.

Epidermal adhesion was tested using a system similar to one described by Bouwkamp (1972), in which a pressurized water jet was used to break the epidermis loose. In our system, an air compressor was attached to a small, metal tank filled with water. A nozzle emitted a sharp stream of water at the desired pressure. Roots were held $\approx 65 \mathrm{~cm}$ from the nozzle. Tank pressure was at $483 \mathrm{kPa}$ and the jet of water hit the root for $3 \mathrm{~s}$. It was determined in preliminary studies that this time and pressure were sufficient to cause the epidermis to break loose from skinning sensitive roots. In the first year, epidermal adhesion was ranked on a 3 -point scale, where $1=$ no break in epidermis, 2 = very small epidermal break, or unsure if broken, and $3=$ epidermis broken loose. In the second year a 5-point scale was used, where 1 = no break, 2 = possibly broken, $3=$ slightly broken, $4=$ epidermis broken, and $5=$ epidermis broken and peeled back. Each 
root was hit with the water jet on opposing sides, for two measurements per root. The number of roots in each treatment ranged from 8 to 15 .

Data were analyzed using the general linear model, regression and least significant difference (LSD) procedures of SAS (SAS Institute, 1988).

\section{Results and Discussion}

Curing. The process of curing roots may or may not decrease skinning depending on cultivar, harvest date and to a limited extent, curing conditions (Table 1). In 'Beauregard', curing reduced skinning in both years and all harvests. In 'Jewel', skinning was reduced in all curing treatments in 1996 , except $30{ }^{\circ} \mathrm{C} /$ $70 \%$ RH. However, in 1997, skinning was not influenced by any curing treatment in the first harvest. In the second harvest, the higher humidity treatments had the least skinning, and all curing treatments were better than uncured roots. In 'Hernandez' in the first harvest of 1996, there was no increase in epidermal adhesion from curing, but all curing treatments increased epidermal adhesion in the second harvest. Skinning was successfully reduced by curing in 'White Delight'. Curing did not promote epidermal adhesion in 'Carolina Rose'. However, there was only one harvest of 'White Delight' and 'Carolina Rose' and results might have varied had more samples been taken. It is possible that temperature, soil moisture, harvest maturity and/ or days after planting could influence the results. From visual observation, all curing treatments promoted wound healing in the roots. Uncured roots did not appear to have complete wound healing at the time other roots were removed from the curing treatments.

Storage. There were statistically significant differences in the curing and storage treatment combinations in some weeks in 'Beauregard' (Table 2). In the 3 Sept. 1996 harvest following 2 weeks of storage, there were differences in responses to the treatments, while there were no treatment differences in weeks 1 or 3 . In the 30 Sept. 1996 harvest, the opposite was true with treatment differences appearing in weeks 1,3 , and 4 , but not after 2 weeks of storage. The standard curing and storage treatment $\left(30^{\circ} \mathrm{C} / 85 \% \mathrm{RH}\right.$ and $15{ }^{\circ} \mathrm{C} / 85 \% \mathrm{RH}$ ) worked well in roots from the first harvest date, but was not the best treatment at the second harvest date. On the second harvest date, treatments using a lower humidity during curing and/or storage seemed to give less skinning. We believe that root/soil moisture levels at harvest may have been a factor in determining which curing and storage treatments gave the best results.

There were treatment differences in weeks 2 and 3 of storage in the 26 Aug. 1997 harvest, and differences in all weeks in the 3 Oct. 1997 harvest (Table 2). The $30{ }^{\circ} \mathrm{C} / 50 \% \mathrm{RH}$ curing treatment had roots that had both the most and the least skinning in both harvests during storage. Therefore, use of low humidity doesn't guarantee a tough epidermis through drying.
Table 1. Effect of curing temperature and relative humidity on epidermal adhesion ratings of sweetpotatoes by harvest date and cultivar.

\begin{tabular}{lccccc}
\hline \hline & & & \multicolumn{3}{c}{ Harvest curing treatment $\left.{ }^{\circ}{ }^{\circ} \mathrm{C} / \mathrm{RH}^{2}\right)$} \\
\cline { 4 - 6 } Cultivar & Date & None & $30 / 85$ & $30 / 70$ & $30 / 50$ \\
\hline Beauregard & $9 / 03 / 96^{\mathrm{x}}$ & $2.8 \mathrm{a}$ & $2.0 \mathrm{~b}$ & $1.8 \mathrm{~b}$ & $1.6 \mathrm{~b}$ \\
& $9 / 30 / 96$ & $3.0 \mathrm{a}$ & $2.0 \mathrm{~b}$ & $1.4 \mathrm{~b}$ & $2.2 \mathrm{~b}$ \\
& $8 / 26 / 97^{\mathrm{w}}$ & $3.4 \mathrm{a}$ & $1.8 \mathrm{~b}$ & $1.5 \mathrm{~b}$ & $1.7 \mathrm{~b}$ \\
Jewel & $10 / 3 / 97$ & $3.5 \mathrm{a}$ & $1.8 \mathrm{~b}$ & $2.3 \mathrm{~b}$ & $2.4 \mathrm{~b}$ \\
& $9 / 30 / 96$ & $2.7 \mathrm{a}$ & $2.0 \mathrm{~b}$ & $1.9 \mathrm{~b}$ & $1.7 \mathrm{~b}$ \\
& $11 / 2 / 96$ & $2.4 \mathrm{a}$ & $1.7 \mathrm{~b}$ & $1.9 \mathrm{ab}$ & $1.5 \mathrm{~b}$ \\
& $8 / 26 / 97$ & $2.0 \mathrm{a}$ & $1.9 \mathrm{a}$ & $1.8 \mathrm{a}$ & $1.5 \mathrm{a}$ \\
Hernandez & $10 / 3 / 97$ & $2.8 \mathrm{a}$ & $1.3 \mathrm{c}$ & $1.6 \mathrm{bc}$ & $1.7 \mathrm{~b}$ \\
& $9 / 30 / 96$ & $2.8 \mathrm{a}$ & $2.5 \mathrm{a}$ & $2.6 \mathrm{a}$ & $2.2 \mathrm{a}$ \\
White Delight & $11 / 4 / 96$ & $2.3 \mathrm{a}$ & $1.8 \mathrm{~b}$ & $1.7 \mathrm{~b}$ & $1.7 \mathrm{~b}$ \\
Carolina Rose & $11 / 4 / 96$ & $2.9 \mathrm{a}$ & $1.5 \mathrm{c}$ & $2.1 \mathrm{~b}$ & $1.7 \mathrm{bc}$ \\
& $9 / 30 / 96$ & $2.7 \mathrm{a}$ & $2.3 \mathrm{a}$ & $2.1 \mathrm{a}$ & $2.2 \mathrm{a}$
\end{tabular}

${ }^{2}$ Ratings were performed at the end of one week of curing.

'Mean separation within rows by Fisher's LSD at $P \leq 0.05$.

${ }^{\mathrm{x}} 1996$ data, skinning rating of 1 to 3 , where $1=$ no break in epidermis, $2=$ very small epidermal break, or unsure if broken, and $3=$ epidermis broken loose.

w1997 data, skinning rating of 1 to 5 , where 1 = no break, 2 = possibly broken, 3 = slightly broken, $4=$ epidermis broken, and $5=$ epidermis broken and peeled back.

Table 2. Epidermal adhesion in 'Beauregard' sweetpotatoes from two harvests in 1996 and 1997. Roots were cured immediately after harvest and evaluated after 1-4 weeks of storage.

\begin{tabular}{|c|c|c|c|c|c|c|}
\hline \multirow[b]{2}{*}{ Harvest date } & \multicolumn{2}{|c|}{ Treatment $\left({ }^{\circ} \mathrm{C} / \mathrm{RH} \%\right)$} & \multicolumn{4}{|c|}{ Skinning value $^{z}$} \\
\hline & Curing & Storage & Week 1 & Week 2 & Week 3 & Week 4 \\
\hline \multirow[t]{10}{*}{3 Sept. 1996} & $30 / 50$ & $15 / 85^{y}$ & 1.4 & $2.0 \mathrm{abc}$ & 1.5 & \\
\hline & & $18 / 70$ & 1.6 & $1.8 \mathrm{abc}$ & 1.3 & \\
\hline & & $18 / 50$ & 1.8 & $2.1 \mathrm{ab}$ & 1.4 & \\
\hline & $30 / 70$ & $15 / 85$ & 1.8 & $1.7 \mathrm{bc}$ & 1.1 & \\
\hline & & $18 / 70$ & 1.6 & $2.3 \mathrm{a}$ & 1.4 & \\
\hline & & $18 / 50$ & 1.9 & $1.9 \mathrm{abc}$ & 1.2 & \\
\hline & $30 / 85$ & $15 / 85$ & 1.8 & $1.5 \mathrm{c}$ & 1.5 & \\
\hline & & $18 / 70$ & 1.5 & $1.5 \mathrm{c}$ & 1.5 & \\
\hline & & $18 / 50$ & 1.8 & $1.8 \mathrm{abc}$ & 1.3 & \\
\hline & & $\mathrm{LSD}_{0.05}$ & NS & 0.5 & NS & \\
\hline \multirow[t]{10}{*}{30 Sept. 1996} & $30 / 50$ & $15 / 85$ & $1.6 \mathrm{ab}$ & 1.5 & $1.4 \mathrm{c}$ & $1.8 \mathrm{~b}$ \\
\hline & & $18 / 70$ & $1.9 \mathrm{a}$ & 1.5 & $2.0 \mathrm{ab}$ & $1.5 \mathrm{~b}$ \\
\hline & & $18 / 50$ & $1.8 \mathrm{ab}$ & 1.4 & $1.6 \mathrm{bc}$ & $1.7 \mathrm{ab}$ \\
\hline & $30 / 70$ & $15 / 85$ & $1.7 \mathrm{ab}$ & 1.8 & $1.9 \mathrm{abc}$ & $1.7 \mathrm{ab}$ \\
\hline & & $18 / 70$ & $1.3 \mathrm{~b}$ & 1.4 & $1.5 \mathrm{bc}$ & $1.6 \mathrm{ab}$ \\
\hline & & $18 / 50$ & $1.7 \mathrm{ab}$ & 1.7 & $1.9 \mathrm{abc}$ & $1.8 \mathrm{ab}$ \\
\hline & $30 / 85$ & $15 / 85$ & $1.8 \mathrm{ab}$ & 1.4 & $2.2 \mathrm{a}$ & $2.1 \mathrm{ab}$ \\
\hline & & $18 / 70$ & $1.8 \mathrm{ab}$ & 1.3 & $1.8 \mathrm{abc}$ & $1.9 \mathrm{ab}$ \\
\hline & & $18 / 50$ & $1.9 \mathrm{a}$ & 1.6 & $1.9 \mathrm{abc}$ & $2.2 \mathrm{a}$ \\
\hline & & $\mathrm{LSD}_{0.05}$ & 0.6 & NS & 0.6 & 0.7 \\
\hline \multirow[t]{10}{*}{26 Aug. 1997} & $30 / 50$ & $15 / 85^{x}$ & ---w & $1.3 \mathrm{~b}$ & $1.4 \mathrm{c}$ & \\
\hline & & $18 / 70$ & 1.2 & $2.2 \mathrm{a}$ & $2.8 \mathrm{a}$ & \\
\hline & & $18 / 50$ & --- & $1.6 \mathrm{ab}$ & $2.1 \mathrm{abc}$ & \\
\hline & $30 / 70$ & $15 / 85$ & --- & $1.6 \mathrm{ab}$ & $2.4 \mathrm{ab}$ & \\
\hline & & $18 / 70$ & --- & $1.7 \mathrm{ab}$ & $1.8 \mathrm{bc}$ & \\
\hline & & $18 / 50$ & 1.7 & $1.5 \mathrm{~b}$ & $2.3 \mathrm{abc}$ & \\
\hline & $30 / 85$ & $15 / 85$ & 1.8 & $1.6 \mathrm{ab}$ & $1.8 \mathrm{bc}$ & \\
\hline & & $18 / 70$ & --- & $1.8 \mathrm{ab}$ & $2.0 \mathrm{bc}$ & \\
\hline & & $18 / 50$ & --- & $1.8 \mathrm{ab}$ & $1.7 \mathrm{bc}$ & \\
\hline & & $\mathrm{LSD}_{0.05}$ & NS & 0.6 & 0.9 & \\
\hline \multirow[t]{10}{*}{3 Oct. 1997} & $30 / 50$ & $15 / 85$ & $1.3 \mathrm{bc}$ & $1.1 \mathrm{~b}$ & $1.3 \mathrm{c}$ & \\
\hline & & $18 / 70$ & $1.9 \mathrm{abc}$ & $1.2 \mathrm{~b}$ & $1.5 \mathrm{abc}$ & \\
\hline & & $18 / 50$ & $1.2 \mathrm{c}$ & $2.2 \mathrm{a}$ & $1.8 \mathrm{abc}$ & \\
\hline & $30 / 70$ & $15 / 85$ & $1.5 \mathrm{abc}$ & $1.3 \mathrm{~b}$ & $1.6 \mathrm{abc}$ & \\
\hline & & $18 / 70$ & $2.2 \mathrm{a}$ & $1.2 \mathrm{~b}$ & $1.3 \mathrm{bc}$ & \\
\hline & & $18 / 50$ & $1.7 \mathrm{abc}$ & $1.2 \mathrm{~b}$ & $2.0 \mathrm{a}$ & \\
\hline & $30 / 85$ & $15 / 85$ & $1.7 \mathrm{abc}$ & $1.4 \mathrm{~b}$ & $1.3 \mathrm{c}$ & \\
\hline & & $18 / 70$ & $1.6 \mathrm{abc}$ & $1.4 \mathrm{~b}$ & $1.9 \mathrm{ab}$ & \\
\hline & & $18 / 50$ & $2.0 \mathrm{ab}$ & $1.6 \mathrm{~b}$ & $1.9 \mathrm{ab}$ & \\
\hline & & $\mathrm{LSD}_{0.05}$ & 0.6 & 0.5 & 0.6 & \\
\hline
\end{tabular}

${ }^{2}$ Mean separation within columns by Fisher's LSD at $P \leq 0.05$.

y 1996 data, skinning value of 1 to 3 , where $1=$ no break in epidermis, 2 = very small epidermal break, or unsure if broken, and $3=$ epidermis broken loose.

x 1997 data, skinning value of 1 to 5 , where 1 = no break, 2 = possibly broken, 3 = slightly broken, $4=$ epidermis broken, and $5=$ epidermis broken and peeled back.

windicates missing data.

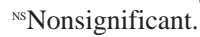


The standard curing and storage conditions of $30{ }^{\circ} \mathrm{C} / 85 \% \mathrm{RH}$ and $15^{\circ} \mathrm{C} / 85 \% \mathrm{RH}$, along with some of the other combinations appeared to give good results.

The epidermal adhesion response in sweetpotatoes is not fixed, even after curing (Table 3). Using 'Beauregard' as an example, when the data were analyzed for differences between weeks, skinning was significantly different between weeks and sometimes became worse after curing and storage. It is unknown what prompts these changes, but they must be internally mediated changes since the roots were held in constant temperature and humidity conditions.

Weight loss in 'Beauregard' was also measured (data not shown), and as expected, the percentage of weight loss was greater in low humidity treatments. Weight loss in the $30{ }^{\circ} \mathrm{C} / 50 \% \mathrm{RH}$ curing and $18{ }^{\circ} \mathrm{C} / 50 \% \mathrm{RH}$ storage combination was $13.4 \%$. Weight loss in the $30{ }^{\circ} \mathrm{C} / 85 \% \mathrm{RH}$ curing and $15{ }^{\circ} \mathrm{C} / 85 \%$ $\mathrm{RH}$ storage combination was $8.9 \%$. Other treatments had intermediate weight loss.

There was very little decay in any of the 'Beauregard' in either year or harvest. In 1996 four roots were lost to decay at curing, but were spread across treatments (two in $30{ }^{\circ} \mathrm{C} / 85 \% \mathrm{RH}$, one in $30{ }^{\circ} \mathrm{C} / 70 \% \mathrm{RH}$, and one in $\left.30^{\circ} \mathrm{C} / 50 \% \mathrm{RH}\right)$. One root was lost to decay during storage in 1997.

In three of the four harvest dates, 'Jewel' showed treatment differences during some of the weeks (Table 4). There were some treatment differences in week 1 of the 3 Sept. 1996 harvest, but all treatments were equivalent in the following weeks. The best treatments in week 1 used lower curing humidities and $18{ }^{\circ} \mathrm{C} / 70 \% \mathrm{RH}$ storage conditions. In the 2 Nov. 1996 harvest, while there were significant differences between treatments, skinning values were very low in all treatments. In the 26 Aug. 1997 harvest, skinning did become higher in the standard treatment $\left(30^{\circ} \mathrm{C} / 85 \%\right.$ $\mathrm{RH}$ and $\left.15{ }^{\circ} \mathrm{C} / 85 \% \mathrm{RH}\right)$ in week 3 and treatment differences appeared. The best epidermal adhesion was in the higher curing humidities, but lower storage humidities. There were

Table 3. Influence of weeks of storage on epidermal adhesion in 'Beauregard' sweetpotatoes when data for all curing and storage treatments are combined for a given harvest date.

\begin{tabular}{lcccc}
\hline \hline Storage & \multicolumn{4}{c}{ Harvest date } \\
\cline { 2 - 5 } week & $9 / 3 / 96$ & $9 / 30 / 96$ & $8 / 26 / 97$ & $10 / 3 / 97$ \\
\hline \multirow{4}{*}{----} & - Skinning value - & --- \\
1 & $1.7 \mathrm{~b}^{\mathrm{y}}$ & $1.7 \mathrm{ab}$ & $1.5 \mathrm{~b}^{\mathrm{x}}$ & $1.7 \mathrm{a}$ \\
2 & $1.9 \mathrm{a}$ & $1.5 \mathrm{~b}$ & $1.7 \mathrm{~b}$ & $1.4 \mathrm{~b}$ \\
3 & $1.3 \mathrm{c}$ & $1.8 \mathrm{a}$ & $2.1 \mathrm{a}$ & $1.6 \mathrm{a}$ \\
4 & -- -w $^{\mathrm{w}}$ & $1.8 \mathrm{a}$ & --- & --- \\
LSD $_{0.05}$ & 0.17 & 0.19 & 0.32 & 0.22
\end{tabular}

${ }^{2}$ Mean separation in columns by Fisher's LSD at $P \leq 0.05$.

${ }^{\mathrm{y}} 1996$ data, skinning value of 1 to 3 , where $1=$ no break in epidermis, 2 = very small epidermis break, or unsure if broken, and $3=$ epidermis broken.

${ }^{\times} 1997$ data, skinning value of 1 to 5 , where $1=$ no break, 2 = possibly broken, 3 = slightly broken, $4=$ epidermis broken, and $5=$ epidermis broken and peeled back.

windicates missing data. no treatment differences in the 3 Oct. 1997 harvest. In 1996, there were two roots lost to decay (one from $30{ }^{\circ} \mathrm{C} / 50 \% \mathrm{RH}$ and $18^{\circ} \mathrm{C} /$ $50 \% \mathrm{RH}$; one from $30{ }^{\circ} \mathrm{C} / 85 \% \mathrm{RH}$, and $\left.15{ }^{\circ} \mathrm{C} / 85 \% \mathrm{RH}\right)$. Only one root was lost to decay in 1997.

In the 30 Sept. 1996 harvest of 'Hernandez', there was less skinning in the lower curing humidity after 2 weeks of storage when compared to treatments with higher curing relative humidities (Table 5); otherwise, treatments were similar. There were no differences in treatments in the 4 Nov. 1996 harvest. Two roots, in different treatments, decayed late in storage.

'Carolina Rose' often had skinning values in the $2+$ range and there were treatment differences in weeks 2 and 3 of storage (Table 5). The standard treatment was one of the best in week 2 and one of the worst in week 3 . The lowest curing and storage humidity $\left(30^{\circ} \mathrm{C} /\right.$ $50 \% \mathrm{RH}$ and $\left.18^{\circ} \mathrm{C} / 50 \% \mathrm{RH}\right)$ appeared to give

Table 4. Epidermal adhesion in 'Jewel' sweetpotatoes for two harvests in 2 years, after different curing and storage conditions.

\begin{tabular}{|c|c|c|c|c|c|c|}
\hline \multirow[b]{2}{*}{ Harvest date } & \multicolumn{2}{|c|}{ Treatment $\left({ }^{\circ} \mathrm{C} / \mathrm{RH} \%\right)$} & \multicolumn{4}{|c|}{ Skinning value $^{z}$} \\
\hline & Curing & Storage & Week 1 & Week 2 & Week 3 & Week 4 \\
\hline \multirow[t]{10}{*}{30 Sept. 1996} & $30 / 50$ & $15 / 85^{y}$ & $1.9 \mathrm{ab}$ & 1.7 & 1.6 & 1.5 \\
\hline & & $18 / 70$ & $1.2 \mathrm{c}$ & 1.7 & 1.8 & 1.7 \\
\hline & & $18 / 50$ & $2.2 \mathrm{ab}$ & 1.5 & 1.7 & 1.6 \\
\hline & $30 / 70$ & $15 / 85$ & $1.7 \mathrm{cb}$ & 1.8 & 1.5 & 2.0 \\
\hline & & $18 / 70$ & $1.2 \mathrm{c}$ & 1.5 & 1.4 & 1.7 \\
\hline & & $18 / 50$ & $2.0 \mathrm{ab}$ & 1.8 & 1.3 & 1.8 \\
\hline & $30 / 85$ & $15 / 85$ & $2.0 \mathrm{ab}$ & 2.0 & 1.5 & 1.5 \\
\hline & & $18 / 70$ & $2.4 \mathrm{a}$ & 1.5 & 1.6 & 1.6 \\
\hline & & $18 / 50$ & $1.9 \mathrm{ab}$ & 1.5 & 1.5 & 1.9 \\
\hline & & $\operatorname{LSD}_{0.05}$ & 0.53 & NS & NS & NS \\
\hline \multirow[t]{10}{*}{2 Nov. 1996} & $30 / 50$ & $15 / 85$ & $1.3 \mathrm{bc}$ & $1.3 \mathrm{bc}$ & $1.5 \mathrm{ab}$ & \\
\hline & & $18 / 70$ & $1.4 \mathrm{bc}$ & $1.1 \mathrm{~d}$ & $1.3 \mathrm{bc}$ & \\
\hline & & $18 / 50$ & $1.5 \mathrm{~b}$ & $1.2 \mathrm{~cd}$ & $1.2 \mathrm{c}$ & \\
\hline & $30 / 70$ & $15 / 85$ & $1.5 \mathrm{~b}$ & $1.5 \mathrm{a}$ & $1.3 \mathrm{bc}$ & \\
\hline & & $15 / 70$ & $1.4 \mathrm{bc}$ & $1.4 \mathrm{ab}$ & $1.3 \mathrm{bc}$ & \\
\hline & & $18 / 50$ & $1.7 \mathrm{a}$ & $1.2 \mathrm{~cd}$ & $1.2 \mathrm{c}$ & \\
\hline & $30 / 85$ & $15 / 85$ & $1.2 \mathrm{c}$ & $1.3 \mathrm{bcd}$ & $1.1 \mathrm{c}$ & \\
\hline & & $18 / 70$ & $1.4 \mathrm{bc}$ & $1.3 \mathrm{bcd}$ & $1.3 \mathrm{bc}$ & \\
\hline & & $18 / 50$ & $1.3 \mathrm{bc}$ & $1.5 \mathrm{a}$ & $1.6 \mathrm{a}$ & \\
\hline & & $\operatorname{LSD}_{0.05}$ & 0.22 & 0.16 & 0.22 & \\
\hline \multirow[t]{10}{*}{26 Aug. 1997} & $30 / 50$ & $15 / 85^{x}$ & ---"w & 1.4 & $1.8 \mathrm{a}$ & \\
\hline & & $18 / 70$ & --- & 1.2 & $1.7 \mathrm{a}$ & \\
\hline & & $18 / 50$ & 1.3 & 1.3 & $1.9 \mathrm{a}$ & \\
\hline & 30,70 & $15 / 85$ & --- & 1.7 & $1.7 \mathrm{a}$ & \\
\hline & & $18 / 70$ & 1.6 & 1.4 & $1.2 \mathrm{~b}$ & \\
\hline & & $18 / 50$ & --- & 1.2 & $1.6 \mathrm{ab}$ & \\
\hline & 30,85 & $15 / 85$ & 1.4 & 1.2 & $2.0 \mathrm{a}$ & \\
\hline & & $18 / 70$ & --- & 1.2 & $1.7 \mathrm{a}$ & \\
\hline & & $18 / 50$ & --- & 1.5 & $1.6 \mathrm{ab}$ & \\
\hline & & $\operatorname{LSD}_{0.05}$ & NS & NS & 0.42 & \\
\hline \multirow[t]{10}{*}{3 Oct. 1997} & $30 / 50$ & $15 / 85$ & 1.3 & 1.4 & 1.3 & \\
\hline & & $18 / 70$ & 1.2 & 1.5 & 1.4 & \\
\hline & & $18 / 50$ & 1.5 & 1.6 & 1.3 & \\
\hline & $30 / 70$ & $15 / 85$ & 1.2 & 1.3 & 1.3 & \\
\hline & & $18 / 70$ & 1.4 & 1.3 & 1.6 & \\
\hline & & $18 / 50$ & 1.6 & 1.1 & 1.4 & \\
\hline & $30 / 85$ & $15 / 85$ & 1.5 & 1.6 & 1.5 & \\
\hline & & $18 / 70$ & 1.2 & 1.6 & 1.4 & \\
\hline & & $18 / 50$ & 1.5 & 1.4 & 1.4 & \\
\hline & & $\mathrm{LSD}_{0.05}$ & NS & NS & NS & \\
\hline
\end{tabular}

${ }^{2}$ Mean separation within columns by Fisher's LSD at $P \leq 0.05$.

${ }^{\mathrm{y}} 1996$ data, skinning value of 1 to 3 , where 1 = no break in epidermis, 2 = very small epidermal break, or unsure if broken, and $3=$ epidermis broken loose.

${ }^{x} 1997$ data, skinning value of 1 to 5 , where 1 = no break, 2 = possibly broken, 3 = slightly broken, $4=$ epidermis broken, and $5=$ epidermis broken and peeled back.

"Indicates missing data.

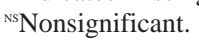

the best results over the 3 weeks of storage. There were no differences among treatments shown). Skinning values averaged 1.3 for were lost to decay with all curing treatments represented in the loss.

It is clear from this study that no set of curing and storage conditions will guarantee roots won't skin when subjected to meoccur on a packing line Susceptibility to skinning in sweetpotatoes changes over time ditions. Curing at $30{ }^{\circ} \mathrm{C}$ and any humidity mal adhesion, however there is no guarante that it will work in every instance. The importance of maintaining humidity is more for weight loss control than the effect on epidermal adhesion. As evidenced by visual observation of wounds and decay incidence, 'White Delight'. Four 'White Delight' roots and with the temperature and humidity con- 
Table 5. Epidermal adhesion in 'Hernandez' and 'Carolina Rose' sweetpotatoes after different curing and storage conditions.

\begin{tabular}{|c|c|c|c|c|c|c|}
\hline \multirow[b]{2}{*}{ Harvest date } & \multicolumn{2}{|c|}{ Treatment $\left({ }^{\circ} \mathrm{C} / \mathrm{RH} \%\right)$} & \multicolumn{4}{|c|}{ Skinning value ${ }^{\mathrm{z}}$} \\
\hline & Curing & $\begin{array}{l}\text { Storage } \\
\end{array}$ & Week 1 & Week 2 & Week 3 & Week 4 \\
\hline \multicolumn{7}{|c|}{ Hernandez } \\
\hline \multirow[t]{10}{*}{30 Sept. 1996} & $30 / 50$ & $15 / 85^{y}$ & 2.1 & $1.4 \mathrm{~b}$ & 1.6 & 2.0 \\
\hline & & $18 / 70$ & 1.7 & $1.4 \mathrm{~b}$ & 1.7 & 1.4 \\
\hline & & $18 / 50$ & 1.7 & $1.5 \mathrm{~b}$ & 1.7 & 2.0 \\
\hline & $30 / 70$ & $15 / 85$ & 2.1 & $2.1 \mathrm{a}$ & 1.9 & 1.6 \\
\hline & & $18 / 70$ & 2.2 & $1.6 \mathrm{~b}$ & 1.6 & 2.2 \\
\hline & & $18 / 50$ & 1.7 & $1.5 \mathrm{~b}$ & 1.5 & 2.2 \\
\hline & $30 / 85$ & $15 / 85$ & 2.0 & $1.8 \mathrm{ab}$ & 1.6 & 1.9 \\
\hline & & $18 / 70$ & 1.8 & $1.4 \mathrm{~b}$ & 1.9 & 2.1 \\
\hline & & $18 / 50$ & 2.1 & $1.8 \mathrm{ab}$ & 1.9 & 2.0 \\
\hline & & $\operatorname{LSD}_{0.05}$ & NS & 0.5 & NS & NS \\
\hline \multirow[t]{10}{*}{4 Nov. 1996} & $30 / 50$ & $15 / 85$ & 2.0 & 1.6 & 1.1 & \\
\hline & & $18 / 70$ & 1.8 & 1.6 & 1.1 & \\
\hline & & $18 / 50$ & 1.6 & 1.5 & 1.2 & \\
\hline & $30 / 70$ & $15 / 85$ & 1.6 & 1.3 & 1.2 & \\
\hline & & $18 / 70$ & 1.3 & 1.7 & 1.1 & \\
\hline & & $18 / 50$ & 1.2 & 1.5 & 1.0 & \\
\hline & $30 / 85$ & $15 / 85$ & 1.5 & 1.5 & 1.2 & \\
\hline & & $18 / 70$ & 1.5 & 1.8 & 1.2 & \\
\hline & & $18 / 50$ & 1.5 & 1.5 & 1.2 & \\
\hline & & $\mathrm{LSD}_{0.05}$ & NS & NS & NS & \\
\hline \multicolumn{7}{|c|}{ Carolina Rose } \\
\hline \multirow[t]{10}{*}{30 Sept. 1996} & $30 / 50$ & $15 / 85^{\mathrm{y}}$ & 2.4 & $2.4 \mathrm{abcd}$ & $2.2 \mathrm{ab}$ & \\
\hline & & $18 / 70$ & 2.2 & $2.1 \mathrm{bcd}$ & $2.1 \mathrm{ab}$ & \\
\hline & & $18 / 50$ & 1.9 & $2.0 \mathrm{~cd}$ & $1.8 \mathrm{~b}$ & \\
\hline & $30 / 70$ & $15 / 85$ & 2.3 & $2.6 \mathrm{abc}$ & $2.7 \mathrm{a}$ & \\
\hline & & $18 / 70$ & 2.3 & $2.8 \mathrm{a}$ & $2.3 \mathrm{ab}$ & \\
\hline & & $18 / 50$ & 2.6 & $2.2 \mathrm{abcd}$ & $2.2 \mathrm{ab}$ & \\
\hline & $30 / 85$ & $15 / 85$ & 2.5 & $1.9 \mathrm{~d}$ & $2.6 \mathrm{a}$ & \\
\hline & & $18 / 70$ & 2.8 & $2.6 \mathrm{ab}$ & $1.9 \mathrm{~b}$ & \\
\hline & & $18 / 50$ & 2.6 & $2.5 a b c$ & $1.7 \mathrm{~b}$ & \\
\hline & & $\operatorname{LSD}_{0.05}$ & NS & 0.57 & 0.66 & \\
\hline
\end{tabular}

${ }^{\mathrm{z}}$ Mean separation within columns by Fisher's LSD at $P \leq 0.05$.

${ }^{y}$ Data on scale of 1 to 3 , where 1 = no break in epidermis, 2 = very small epidermal break, or unsure if broken, and 3 = epidermis broken loose.

Ns Nonsignificant.

it appeared that roots were cured in all treatments. There was little decay in this study and it was scattered across treatments. Lower humidity did in some cultivars on occasion result in less skinning, but there were exceptions to this. Higher storage temperatures did not appear to have much influ- conditions at harvest. There are significant environmental changes that occur by the later harvest dates. We also confirmed our observation from commercial operations that susceptibility to skinning does fluctuate during the storage period after curing. Epidermal adhesion is a dynamic system, possibly due to internal signals in the root. This could be a point for further study. The standard conditions of curing at $30^{\circ} \mathrm{C} / 85 \% \mathrm{RH}$ and storing at $15{ }^{\circ} \mathrm{C} / 85 \% \mathrm{RH}$, are still a reasonable practice.

\section{Literature Cited}

Bouwkamp, J.C. , L.E. Scott, and W.L. Harris. 1972. Rapid determination of "skin-toughness" in sweetpotato. HortScience 7:473-474.

Boyette, M.D., E. Estes., A.R. Rubin, and K.A. Sorensen. 1997. The postharvest handling of sweetpotatoes. N.C. Coop. Ext. Serv. AG-41310-B, Raleigh, N.C.

Boyette, M.D. and H.E. Stewart. 1994. Horizontal ventilation for long-term storage of sweetpotatoes. Presented at the Dec. 1994 ASAE Intl. Meeting, Paper No. 94-6583. ASAE, 2950 Niles Rd., St. Joseph, Mich. 49085-9659

Hardenburg, R.E., A.E. Watada, and C.Y. Wang. 1986. The commercial storage of fruits, vegetables and florist and nursery stocks. USDA Handbook 66, Washington, D.C.

Kushman, L.J. 1975. Effect of injury and relative humidity during curing on weight and volume loss of sweet potatoes during curing and storage. HortScience 10:275-277.

La Bonte, D.R. and M.E. Wright. 1993. Image analysis quantifies reduction in sweetpotato skinning injury by preharvest canopy removal. HortScience 28:1201.

Miller, F.E. 1943. Utilization of flue-heated tobacco barns for sweetpotato storage. USDA Farmers' Bul. No. 1267. Washington, D.C.

Picha, D.H. 1986. Weight loss in sweet potatoes during curing and storage: contribution of transpiration and respiration. J. Amer. Soc. Hort. Sci. 111(6):889-892.

epidermal adhesion. The epiderma adhesion differences in cultivars seem to be more influenced by genetics, harvest dates/ maturity, and growing season. It was not clear in this study if the differences between harvest dates in a given cultivar and year were due to harvest maturity or because of the
SAS Institute, Inc. 1988. SAS/STAT user's guide. Release 6.03 ed. SAS Inst., Cary, N.C.

Thompson, H.C. 1925. Storage of sweet potatoes. USDA Farmers' Bul. No. 1442. Washington, D.C. 